A RCHIWA, BIBLIOTEKI

I MUZEA KOŚCIELNE 112 (2019)

https://doi.org.10.31743/abmk.2019.112.32

ARTUR HAMRYSZCZAK* - LUBLIN

\title{
OGÓLNOPOLSKA KONFERENCJA NAUKOWA OJCIEC HENRYK DAMIAN WOJTYSKA 1933-2009. HISTORYK KOŚCIOLA I DYDAKTYK W DZIESIATTA ROCZNICE ŚMIERCI. LUBLIN 9 XII 2019 ROKU
}

W gmachu Centrum Transferu Wiedzy Katolickiego Uniwersytetu Lubelskiego Jana Pawła II odbyła się w dniu 9 grudnia 2019 r. ogólnopolska konferencja naukowa, zorganizowana przez Ośrodek Archiwów, Bibliotek i Muzeów Kościelnych KUL, poświęcona wybitnemu badaczowi historii Kościoła, pasjoniście prof. Henrykowi Wojtysce CP.

Obrady zainaugurowała poranna msza święta w kościele akademickim pod przewodnictwem bpa prof. Jana Kopca, ordynariusza diecezji gliwickiej i delegata episkopatu ds. Stowarzyszenia Archiwistów Kościelnych. Jest on również członkiem Rady ds. Kultury i Ochrony Dziedzictwa Kulturowego i Zespołu ds. Sanktuariów. W swojej homilii bp J. Kopiec przybliżył postać o. prof. H. Wojtyski jako duchownego oraz historyka Kościoła, który umiejętnie łączył powołanie zakonne z pracą na niwie nauki.

Otwarcia sympozjum i powitania uczestników dokonał dr Artur Hamryszczak, dyrektor Ośrodka ABMK. W swoim krótkim wystąpieniu zwrócił uwagę na związki o. H. Wojtyski z KUL oraz jego wkład w rozwój uniwersytetu.

Ks. dr hab. prof. KUL Waldemar W. Żurek SDB szczegółowo przedstawił jego biografię (Sylwetka Ojca Profesora Henryka Damiana Wojtyski CP). Henryk Damian Wojtyska urodził się 13 maja1933 r. w Regiminie k. Ciechanowa, zmarł 24 marca 2009 r. w Łodzi. W 1950 r. wstąpił do Zgromadzenia Pasjonistów, a w 1957 r. przyjął święcenia kapłańskie. W latach 1958-1962 studiował historię Kościoła na Papieskim Uniwersytecie Gregoriańskim w Rzymie, gdzie uzyskał doktorat na podstawie pracy Card. Hosius, Legate to the Council of Trent (Rome 1967). Po powrocie do Polski wykładał w seminarium pasjonistów, a od 1969 r. podjął pracę

\footnotetext{
* Artur Hamryszczak - dr historii; asystent naukowy w Ośrodku Archiwów, Bibliotek i Muzeów Kościelnych KUL; e-mail: artur.hamryszczak@kul.pl

https://orcid.org/0000-0002-2578-9971
} 
naukową w Katolickim Uniwersytecie Lubelskim. Habilitację uzyskał w 1975 r. na podstawie pracy Papiestwo Polska 1548-1563. Dyplomacja, Lublin 1977. W latach 1980/1981 wykładał historię Kościoła w Newman College w kanadyjskim Edmonton, jako visiting professor. Po powrocie objął funkcję Prorektora ds. Młodzieży KUL (1981-1983). W latach 1984-1994 był kierownikiem ds. edytorskich w Polskim Instytucie Historycznym w Rzymie, gdzie zapoczątkował wydawanie serii Acta Nuntiaturae Polonae. H. Wojtyska był członkiem Papieskiego Komitetu Nauk Historycznych (1984-2004), Lubelskiego Towarzystwa Naukowego i Towarzystwa Naukowego KUL, Akademii św. Karola w Mediolanie i Komisji Dziejów Odrodzenia i Reformacji przy Komitecie Nauk Historycznych PAN. Do roku 2004 był także konsultorem Komisji Nauki Wiary w sekcji historycznej przy Episkopacie Polski.

Kolejny referat wygłosił, dr hab. prof. UKSW Waldemar Linke CP, Pasjonista w epoce przemian soborowych: Ojciec Profesor Damian Henryk Wojtyska CP o tożsamości i charyzmacie Zgromadzenia Męki Jezusa Chrystusa. W swoim wystąpieniu długoletni przełożony polskiej prowincji pasjonistów przedstawił o. H. Wojtyskę poprzez jego życie i działalność we wspólnocie zakonnej. Ukazał ograniczenia z którymi się borykał w zakonie, wynikające zarówno z sytuacji społeczno-politycznej w Polsce, jak i z wprowadzania reform soborowych. Prelegent zwrócił również uwagę na dużą rolę o. H. Wojtyski w spisaniu historii zgromadzenia na ziemiach polskich oraz inne jego badania szczegółowe.

Następny referat był autorstwa bpa prof. Jana Kopca, Kontakty i zwiazki naukowe Ojca Henryka Damiana Wojtyski z Rzymem. W swoim wystąpieniu hierarcha przedstawił czas studiów o. H. Wojtyski na Uniwersytecie Gregoriańskim oraz podjęte przez niego prace badawcze zwieńczone doktoratem. Szczegółowo opisał również jego kolejny pobyt naukowy w Rzymie od połowy lat 80 . XX wieku, kiedy to stworzył zespół naukowy wydający akta nuncjatury warszawskiej (Acta Nuntiaturae Polonae), kontynuując przedwojenne dzieło Polskiej Akademii Umiejętności. Wykład bp prof. J. Kopca był szczególnie cenny gdyż był on członkiem wspomnianego zespołu wydawniczego.

Dr Stanisław A. Bogaczewicz, przedstawił działalność o. H. Wojtyski jako Prorektora KUL w okresie stanu wojennego (Katolicki Uniwersytet Lubelski w okresie stanu wojennego i działalność Ojca Damiana Wojtyski jako Prorektora ds. studentów). W swoim wystąpieniu przedstawił sytuację KUL w okresie PRL i liczne szykany którym podlegało środowisko naukowe i studenckie. Opisał czas powstania w Lublinie NSZZ ,Solidarność” i wprowadzenie stanu wojennego, co wywołało sprzeciw środowiska akademickiego. S. Bogaczewicz zaangażowany w działalność opozycyjną jako student KUL, szczegółowo przedstawił działania studentów i pracowników uniwersytetu m.in. strajk okupacyjny czy też manifestacje. W referacie wyakcentował szczególną rolę H. Wojtyski, który piastował wówczas funkcję Prorektora ds. studentów (1981-1983). Prelegent ukazał na jednostkowych przykładach, jak o. H. Wojtyska bronił studentów KUL przed represjami ze strony komunistycznych władz.

Prowincjał polskiej prowincji pasjonistów dr Łukasz Andrzejewski CP, przedstawił referat Wkład Ojca Profesora Damiana Henryka Wojtyski CP do histo- 
riografii Zgromadzenia Męki Jezusa Chrystusa. Prelegent jest autorem ostatniej części dziejów polskiej gałęzi zgromadzenia, będącej kontynuacją serii wydanej przez o. H. Wojtyskę. Omówił on również dwa pierwsze tomy Historii Zgromadzenia Pasjonistów w Polsce, a także archiwalia proweniencji kościelnej z których korzystał o. H. Wojtyska. Przybliżył również spuściznę aktową tego historyka, która jest przechowywana $\mathrm{w}$ archiwum zgromadzenia.

W nawiązaniu do tego wykładu dr Artur Hamryszczak przedstawił referat Wktad Ojca Damiana Henryka Wojtyski w archiwistykę kościelna. W swoim rozważaniu wskazał on na naukowe środowisko z którym zetknął się o. H. Wojtyska podczas studiów na rzymskim Uniwersytecie Gregoriańskim. Wśród nich, wiodącą postacią był ks. Walerian Meysztowicz, który wgłębił go w tajniki archiwów rzymskich. Po powrocie do Polski o. H. Wojtyska nawiązał kontakty naukowe z ks. Stanisławem Librowskim i o. Hieronimem Wyczawskim OFM. Owocem współpracy naukowej były publikacje naukowe m.in. na łamach półrocznika „Archiwa, Biblioteki i Muzea Kościelne” oraz uporządkowanie archiwum zakonnego pasjonistów w Polsce. Referent przedstawił również działalność źródłoznawczą, która skutkowała edycjami krytycznymi dokumentacji np. kardynała Stanisława Hozjusza.

Referat ks. prof. Andrzeja Kopiczki Wspótpraca naukowa Ojca Profesora Henryka Damiana Wojtyski ze środowiskiem naukowym w Olsztynie, został odczytany z powodu nieobecności autora. Wspomniana współpraca dotyczyła edycji źródłowej dokumentacji kard. Stanisława Hozjusza, którego podjęła się diecezja warmińska w związku z przygotowywaniem procesu beatyfikacyjnego tego hierarchy. Powołano wówczas zespół wydawniczy w skład którego wszedł o. H. Wojtyska. W latach 90. XX wieku wspomógł on naukowo tworzony Wydział Teologiczny Uniwersytetu Warmińsko-Mazurskiego w Olsztynie.

Ostatni referat Prace naukowe napisane pod kierownictwem Ojca Profesora Damiana Henryka Wojtyski przedstawił Krzysztof Perzyna. Omówił on tematykę 34 prac magisterskich, które powstały na jego seminarium oraz trzy doktoraty, których był promotorem.

Na zakończenie sesji głos zabrał również emerytowany Rektor KUL ks. prof. Stanisław Wilk, który wydał akta nuncjusza Achille Rattiego w ramach prac zespołu edycyjnego akt nuncjatury prowadzonym przez o. prof. H. Wojtyskę. Również postali uczestnicy konferencji dzielili się swoimi spostrzeżeniami i wspomnieniami dotyczącymi tej postaci. Planowane jest wydanie książki pokonferencyjnej, wzbogaconej również o inne teksty i materiały fotograficzne.

Słowa kluczowe: Henryk Damian Wojtyska; pasjoniści; akta nuncjatury, Katolicki Uniwersytet Lubelski

Keywords: Henryk Damian Wojtyska; the Passionists; the records of the Apostolic nunciature; the Catholic University of Lublin 


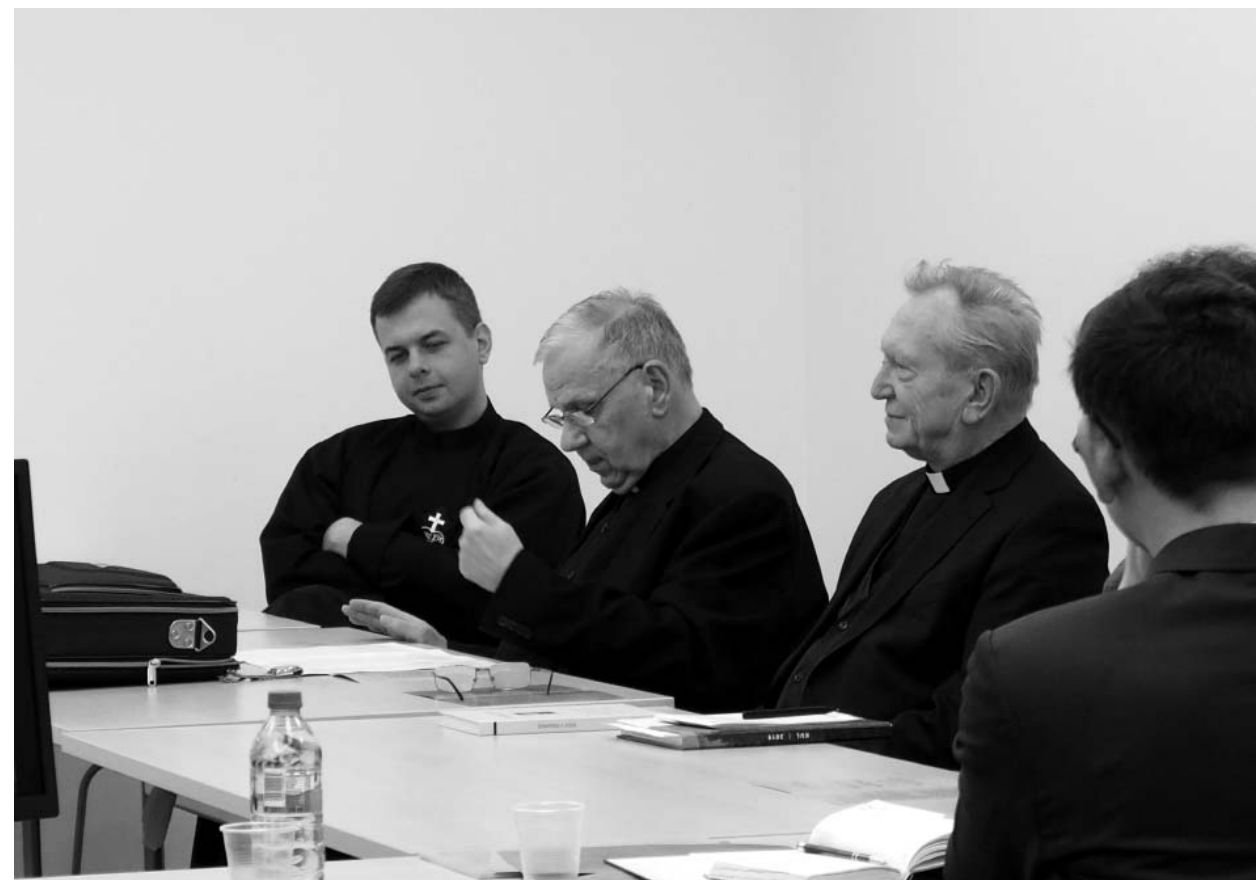

Fot. 1. Wystąpienie bpa prof. Jana Kopca. Z prawej strony ks. prof. Stanisław Wilk. Pierwszy z lewej o. dr Łukasz Andrzejewski CP, prowincjał polskich pasjonistów. Fot. Paulina Tomczyk.

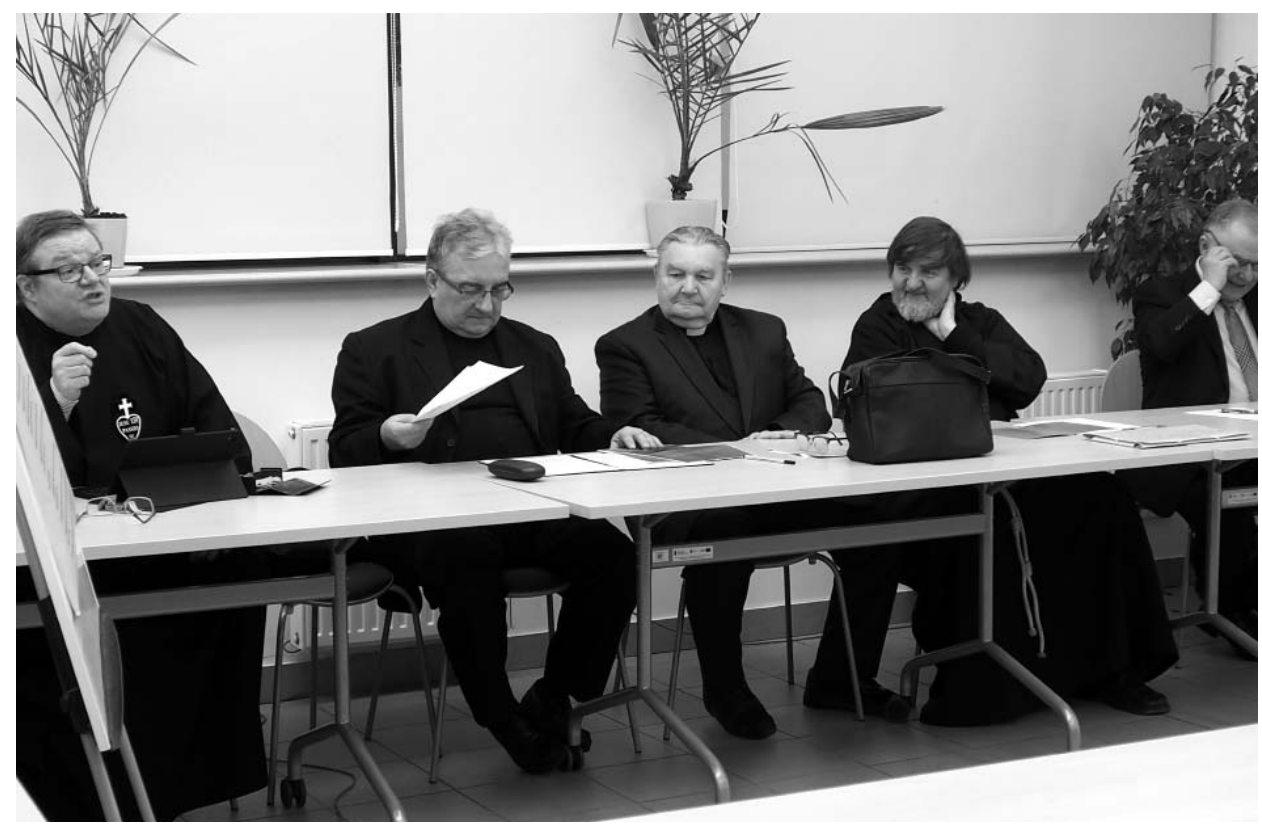

Fot. 2. Wystąpienie o. prof. Waldemar Linke CP, obok. ks. prof. Waldemar W. Żurek SDB, ks. prof. Anzelm Weiss, o. prof. Roland Prejs OFMCap., dr Stanisław A. Bogaczewicz. Fot. Paulina Tomczyk. 